\title{
Quercetin promotes MC3T3-E1 cell growth via PI3K/Akt signaling pathway
}

\author{
Haidong Liang*, Fang Yu \\ Dalian Medical University, Dalian City, China \\ *For correspondence: Email: tsfkmei@aliyun.com; Tel: +86-0411-84671291
}

Sent for review: 4 July 2018

Revised accepted: 21 November 2018

\begin{abstract}
Purpose: To investigate the effect of quercetin on mouse osteoblast MC3T3-E1 cell growth and the molecular mechanisms involved.

Methods: The effect of quercetin on MC3T3-E1 cells growth, cell cycle distribution, bone-related genes and PISK/Akt signaling pathway were determined in vitro using MTT assay, flow cytometry, qPCR and western blot, respectively.

Results: Qercetin promoted MC3T3-E1 cell growth, as revealed from MTT assay. Flow cytometry showed that quercetin administration resulted in accumulation of cells in the $S$ phase. In addition, quercetin up-regulated mRNA expression levels of osteopontin, ALP, osteoprotegerin, osteocalcin and RunX-2, and increased phosphorylation of AKT.

Conclusion: Quercetin enhances the growth of MC3T3-E1 cells via a mechanism involving accumulation of cells in S phase, increasing mRNA expression levels of bone-associated genes, and increasing the phosphorylation of AKT.
\end{abstract}

Keywords: Quercetin, MC3T3-E1 cells, AKT phosphorylation, Osteopontin, Osteoprotegerin, Osteocalcin, RunX-2

\begin{abstract}
This is an Open Access article that uses a funding model which does not charge readers or their institutions for access and distributed under the terms of the Creative Commons Attribution License (http://creativecommons.org/licenses/by/4.0) and the Budapest Open Access Initiative (http://www.budapestopenaccessinitiative.org/read), which permit unrestricted use, distribution, and reproduction in any medium, provided the original work is properly credited.

Tropical Journal of Pharmaceutical Research is indexed by Science Citation Index (SciSearch), Scopus, International Pharmaceutical Abstract, Chemical Abstracts, Embase, Index Copernicus, EBSCO, African Index Medicus, JournalSeek, Journal Citation Reports/Science Edition, Directory of Open Access Journals (DOAJ), African Journal Online, Bioline International, Open-J-Gate and Pharmacy Abstracts
\end{abstract}

\section{INTRODUCTION}

Quercetin is a flavonoid compound present in a variety of fruits and vegetables such as grapefruit, mandarin oranges, and onions [1]. It is a free radical scavenger and a chelator of metal ions. Studies have revealed that quercetin exerts cytoprotective through its anti-inflammatory and antioxidant properties [2-4]. In addition, it possesses anti-cancer and anti-allergy activities [2]. Quercetin enhances the growth and development of osteoblasts through positive interaction with them, and it suppresses the bone-resorption activity of osteoclasts [5-8].

Skeletal defects requiring bone-graft procedures are one of the most serious challenges confronting millions of patients annually worldwide [9]. It has been estimated that 2.2 million bone-grafting surgeries are carried out annually worldwide [10]. Osteopenia is often associated with increased incidence of bone fracture, delayed healing of bone fractures, and poor quality of life of diabetic patients [11,12]. Therefore, the search for effective drugs which 
can control the development of diabetic osteopenia is of great significance for patients with diabetic osteopenia.

This study was aimed at investigating the putative beneficial influence of quercetin in a mouse cell osteoblast MC3T3-E1 model of diabetic osteopenia.

\section{EXPERIMENTAL}

\section{MC3T3-E1 cell culture}

Mouse MC3T3-E1 cells were obtained from Type Culture Collection of Chinese Academy of Sciences (Shanghai, China). They were cultured routinely $37{ }^{\circ} \mathrm{C}$ in Dulbecco's Modified Eagle's Medium (DMEM) (Gibco, USA) supplemented with $10 \%$ fetal bovine serum (FBS) (Gibco, USA), penicillin (100 U/mL) and streptomycin $(100 \mu \mathrm{g} / \mathrm{mL})$ in a humidified atmosphere containing $5 \% \mathrm{CO}_{2}$.

\section{Cell proliferation assay}

Cell proliferation was determined using MTT assay. The MC3T3-E1 cells were cultured in 6well plates to $80 \%$ confluence, and the old medium was replaced with a medium containing quercetin at concentrations of $0.4,0.6$, and 0.8 $\mathrm{mmol} / \mathrm{L}$, followed by incubation for $48 \mathrm{~h}$. The negative control consisted of cell cultures without quercetin. Thereafter, $20 \mu \mathrm{L}$ of $0.5 \mathrm{mg} / \mathrm{mL}$ MTT (Sigma-Aldrich) was added to each well and the wells were incubated $37^{\circ} \mathrm{C}$ for $4 \mathrm{~h}$. Then, the medium was removed and the resultant formazan crystals were solubilized in $150 \mu \mathrm{L}$ of dimethylsulfoxide (Sigma-Aldrich), and absorbance was read at $490 \mathrm{~nm}$ in a SpectraMax 360 pc microplate reader (Molecular Devices, CA, USA).

\section{Flow cytometric analysis of changes in cell cycle}

The MC3T3-E1 cells were harvested with tryptic digestion and centrifuged for $6 \mathrm{~min}$ at $1200 \mathrm{rpm}$. The cell pellet was rinsed twice with $3 \mathrm{~mL}$ of PBS, centrifuged and fixed for $2 \mathrm{~h}$ in ice-cooled $70 \%$ ethanol at $4{ }^{\circ} \mathrm{C}$. The fixed cells were recovered by centrifugation and the cells were re-suspended in $3 \mathrm{~mL}$ of PBS, sieved through a 400-mesh net, and centrifuged for $3 \mathrm{~min}$ at 3000 rpm. Thereafter, the cells were stained with $1 \mathrm{~mL}$ of $100 \mu \mathrm{g} / \mathrm{mL}$ propidium iodide (Sigma, MO, USA) at $4{ }^{\circ} \mathrm{C}$ for $30 \mathrm{~min}$ in the dark. The distribution of cells in the cell cycle phases was measured using a flow cytometer (CyFlowß Cube, Görlitz, Germany) at excitation and emission wavelengths of $488 \mathrm{~nm}$ and $630 \mathrm{~nm}$, respectively.

\section{Quantitative real-time PCR (qPCR)}

Total RNA was isolated from the MC3T3-E1 cells with TRIzol reagent (Invitrogen). The concentration and the purity of RNA were determined by measuring the absorbance at 260/280 nm using a spectrophotometer (NANODrop). The isolated RNA (2 $\mu \mathrm{g})$ was reversetranscribed to cDNA with revertAid kit (Fermentas, USA) using commercial first-strand cDNA synthesis kit. SYBR green chemistry was used to perform quantitative determination of osteopontin, ALP, osteoprotegerin, osteocalcin and RunX-2 and $\beta$-actin transcript levels following an optimized protocol. The primer sequence of the genes of interest are indicated in Table 1.

Table 1: Primer sequences for real-time PCR analysis of gene expression*

\begin{tabular}{ll}
\hline Gene name & Primer sequence \\
\hline OC & CCTTCATGTCCAAGCAGGA \\
& GGCGGTCTTCAAGCCATAC \\
OPN & CCTCCCGGTGAAAGTGAC \\
& CTGTGGCGCAAGGAGATT \\
OPG & GTTCCTGCACAGCTTCACAA \\
& AAACAGCCCAGTGACCATTC \\
ALP & TATGTCTGGAACCGCACTGAAC \\
& CACTAGCAAGAAGAAGCCTTTGG \\
Runx2 & ATCCAGCCACCTTCACTTACACC \\
& GGGACCATTGGGAACTGATAGG \\
ß-actin & GGGTCAGAAGGATTCCTATG \\
& GGTCTCAAACATGATCTGGG \\
\hline
\end{tabular}

${ }^{*}$ For each gene, the first and second sequences refer to forward and reverse

\section{Western blot assay}

At various time points, cells were scraped and disrupted with lysis buffer to obtain cell lysates. Equal amounts of proteins in lysate samples were subjected to $10 \%$ sodium dodecyl sulfatepolyacrylamide gel electrophoresis and transferred to polyvinylidene difluoride membrane. After incubating the membrane with specific primary antibodies and horseradish peroxidase-conjugated secondary antibodies, signals were detected using chemiluminescent substrate (KPL Guildford, UK), and the blot intensities were quantified using BandScan software (Glyko, CA).

\section{Statistical analysis}

Data are presented as mean \pm SD. Statistical comparisons were performed by one-way analysis of variance (ANOVA) followed by Dunnett's t-test. GraphPad Prism software 
(GraphPad Software Inc., La Jolla, CA) was used to analyze experimental data. Values of $p<0.05$ were considered statistically significant.

\section{RESULTS}

Administration of quercetin for 2 weeks significantly increased MC3T3-E1 cell growth. The increase was significant at quercetin doses of $0.40,0.68$ and $0.80 \mathrm{mmol} / \mathrm{L}$, when compared to the control (Table 2).

Table 2: Effect of quercetin on MC3T3-E1 cell growth

\begin{tabular}{lc}
\hline $\begin{array}{l}\text { Dose } \\
(\mathbf{m m o l} / \mathbf{L})\end{array}$ & $\begin{array}{c}\text { Degree of } \\
\text { proliferation (\%) }\end{array}$ \\
\hline 0 & - \\
0.4 & 8.35 \\
0.6 & 11.06 \\
0.8 & 15.38 \\
\hline
\end{tabular}

The results of cell cycle distribution revealed that in MC3T3-E1 cell lines, $48 \mathrm{~h}$ incubation with quercetin resulted in accumulation of cells in the $+S$ phase, with concomitant reduction of percentage of cells in the G0/G1 phase (Table 3). The percentage of MC3T3-E1 cells accumulated in $S$ phase after treatment with quercetin increased from $27.2 \%$ (control) to 42.8 $\%$.

Table 3: Effect of quercetin on MC3T3-E1 cell cycle distribution

\begin{tabular}{lcccc}
\hline $\begin{array}{l}\text { Dose } \\
\text { (mmol/L) }\end{array}$ & G0/G1 & S & G2/M & S+G2 \\
\hline 0 & 68.2 & 27.2 & 4.6 & 31.8 \\
0.4 & 60.3 & 35.5 & 4.2 & 34.8 \\
0.6 & 56.8 & 38.4 & 4.8 & 38.2 \\
0.8 & 52.3 & 42.8 & 4.9 & 42.7 \\
\hline
\end{tabular}

The mRNA expression levels of osteopontin, ALP, osteoprotegerin, osteocalcin and RunX-2 in the control and quercetin-treated groups were investigated. As shown in Table 4, administration of quercetin at different doses significantly and dose-dependently increased the mRNA levels of all the five genes, relative to the control $(p<$ 0.05).
Phosphorylated Akt (p-Akt) and Akt protein levels were determined by western blot. There were no significant differences in protein expression of Akt between the quercetin group and the control group (Figure I). However, p-Akt expression was significantly increased in quercetin-treatment group (Figure 1). The relative intensity of $p$ Akt/total Akt was dose-dependently and significantly increased in the quercetin-МС3T3E1 cells, when compared to the control group.

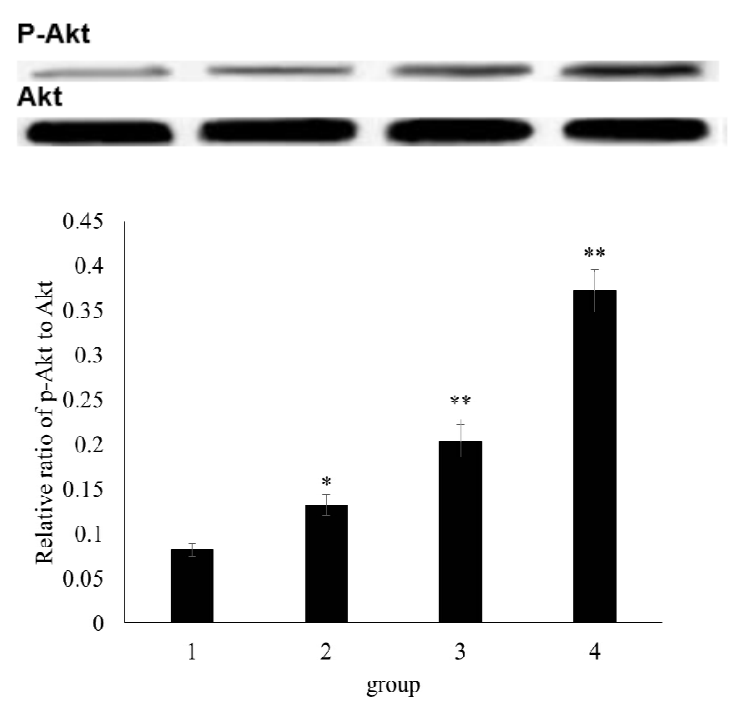

Figure 1: Effect of quercetin on p-Akt and Akt protein levels in MC3T3-E1 cells

\section{DISCUSSION}

The present study investigated the effect of quercetin on mouse MC3T3-E1 cell growth. It was found that quercetin promoted mouse MC3T3-E1 cell growth. Each phase of cell cycle has checkpoints that can promote cell cycle arrest, enabling activation of repair mechanisms and fixing the damage. The results obtained in this study showed that in mouse MC3T3-E1 cell lines, quercetin induced cell cycle arrest in $S$ phase. Thus, the $S$ phase arrest appears to be a possible mechanism for the growth promotion induced by quercetin. Cell population increased in $S$ phase but decreased in $\mathrm{G} 1$ phase. This indicates that all phases of cell cycle were advanced, thereby shortening the proliferation cycle.

Table 4: Effect of quercetin on the expression of bone-related genes in MC3T3-E1 cells

\begin{tabular}{llllll}
\hline $\begin{array}{l}\text { Dose } \\
(\mathbf{m m o l} / \mathrm{L})\end{array}$ & Osteopontin & ALP & Osteoprotegerin & Osteocalcin & RunX-2 \\
\hline 0 & $1.592 \pm 0.132$ & $1.242 \pm 0.107$ & $1.426 \pm 0.122$ & $1.173 \pm 0.105$ & $0.932 \pm 0.083$ \\
0.4 & $2.036 \pm 0.183^{\star *}$ & $1.638 \pm 0.142^{*}$ & $1.936 \pm 0.145^{\star *}$ & $1.895 \pm 0.149^{* *}$ & $1.216 \pm 0.113^{*}$ \\
0.6 & $2.572 \pm 0.218^{\star *}$ & $2.316 \pm 0.199^{\star *}$ & $2.495 \pm 0.211^{\star *}$ & $2.553 \pm 0.206^{\star *}$ & $1.941 \pm 0.162^{* *}$ \\
0.8 & $3.158 \pm 0.273^{\star *}$ & $2.814 \pm 0.238^{* *}$ & $2.963 \pm 0.242^{\star *}$ & $3.472 \pm 0.294^{* *}$ & $2.605 \pm 0.182^{* *}$ \\
\hline
\end{tabular}


In this study, the quercetin treatment of mouse MC3T3-E1 cells was associated with bonerelated genes. Quercetin treatment was also shown to increase the expression levels of osteopontin, ALP, osteoprotegerin, osteocalcin and RunX-2 mRNA in mouse MC3T3-E1 cells, indicating that these molecules are crucial for osteoblast proliferation and differentiation. Quercetin treatment was also shown to increase the phosphorylation of Akt. Thus, it is possible that quercetin treatment promotes mouse MC3T3-E1 cells growth via the PI3K/Akt signal pathway. These findings indicate the beneficial effect of quercetin on diabetes-induced osteopenia, and indicate the feasibility of developing quercetin as a potential therapeutic drug for osteopenia.

\section{CONCLUSION}

The findings of this study indicate that quercetin exerts a beneficial effect on osteopenia. Thus, the results raise the possibility of developing quercetin as a potential therapeutic drug for osteopenia disease.

\section{DECLARATIONS}

\section{Conflict of Interest}

No conflict of interest associated with this work.

\section{Contribution of Authors}

The authors declare that this work was done by the authors named in this article and all liabilities pertaining to claims relating to the content of this article will be borne by them.

\section{REFERENCES}

1. Jung $M, B u$ SY, Tak KH, Park JE, Kim E. Anticarcinogenic effect of quercetin by inhibition of insulin-like growth factor (IGF)-1 signaling in mouse skin cancer. Nutr Res Pract. 2013; 7: 439-445
2. Anand David AV, Arulmoli R, Parasuraman S. Overviews of biological importance of quercetin: a bioactive flavonoid. Pharmacogn Rev, 2016; 10: 84-89.

3. Kaiserová $H$, Simůnek $T$, van der Vijgh $W J$, Bast $A$, Kvasnicková E. Flavonoids as protectors against doxorubicin cardiotoxicity: role of iron chelation, antioxidant activity and inhibition of carbonyl reductase. Biochim Biophys Acta, 2007; 1772: 1065-1074

4. Li Y, Chen M, Xu Y, Yu X, Xiong T, Du M, Sun J, Liu L, Tang $Y$, Yao $P$. Iron-mediated lysosomal membrane permeabilization in ethanol-induced hepatic oxidative damage and apoptosis: protective effects of quercetin. Oxid Med Cell Longev, 2016; 2016: ID 4147610

5. Wong RW, Rabie $A B$. Effect of quercetin on preosteoblasts and bone defects. Open Orthop J, 2008; 2: 27-32

6. Wattel A, Kamel S, Prouillet C, Petit JP, Lorget F, Offord E, Brazier M. Flavonoid quercetin decreases osteoclastic differentiation induced by RANKL via a mechanism involving NF kappa $B$ and AP-1. J Cell Biochem, 2004; 92: 285-95

7. Woo JT, Nakagawa H, Notoya M, Yonezawa T, Udagawa N, Lee IS, Ohnishi M, Hagiwara H, Nagai K. Quercetin suppresses bone resorption by inhibiting the differentiation and activation of osteoclasts. Biol Pharm Bull, 2004; 27: 504-509

8. Wattel A, Kamel S, Mentaverri R, Lorget F, Prouillet $C$, Petit JP, Fardelonne P, Brazier M. Potent inhibitory effect of naturally occurring flavonoids quercetin and kaempferol on in vitro osteoclastic bone resorption. Biochem Pharmacol, 2003; 65: 35-42

9. Kroeze RJ, Helder MN, Govaert LE, Smit TH. Biodegradable polymers in bone tissue engineering. Materials, 2009; 2: 833-856

10. Costa-Pinto AR, Reis RL, Neves NM. Scaffolds based bone tissue engineering: the role of chitosan. Tissue Eng B Rev, 2011; 17: 331-347

11. Forsén L, Meyer HE, Midthjell K, Edna TH. Diabetes mellitus and the incidence of hip fracture: results from the Nord-Trøndelag Health Survey. Diabetologia, 1999; 42: 920-925

12. Vestergaard P. Discrepancies in bone mineral density and fracture risk in patients with type 1 and type 2 diabetes-a meta-analysis. Osteoporos Int, 2007; 18: 427-444 